\title{
CHAPTER SEVEN
}

\section{New Directions: The Deconstructing 'Tis Pity?: Derrida, Barthes and Ford}

\author{
Mark Houlahan
}

At the famous climax of 'Tis Pity, Giovanni enters the last scene of the play and, as he knows, his life, 'with a heart upon his dagger', with which be-hearted implement he stabs his enemy and brother-inlaw Soranzo, before himself being fatally stabhed in the ensuing melée. The heart, it seems, is Annabella's, removed from her after Giovanni's loving, surgical sacrifice of his pregnant sister/wife in the scene before. The 'seems' here is crucial, for at first this is not clear, neither to the onstage audience, waiting for Giovanni to arrive at the banquet, nor to an audience watching the play or those reading it. The eloquent Giovanni exults in providing the explanation to both groups. To begin, he sounds like a dilettante who has read rather too many poems by John Donne, whose Songs and Sonets was also published in 1633: '[...] I digg'd for food I In a much richer mine than gold or stone I Of any value balanc'd [...]'; Giovanni's rhetoric here is close to Donne's at the opening of 'Loves Alchymie': 'Some that have deeper digg'd loves Myne then I, Say, where his centrique happinesse doth lie: I have lov'd, and got and told [.. . $]^{\prime 2}$

Giovanni's proclamation is obscure, so he clarifies the referent, in a gestic moment aligning his gruesome prop with the following: "tis a heart, | A heart, my lords, in which is mine entombed [...] |'Tis Annabella's heart, 'tis; why d'ye startle?' (V.vi.24-30). This is perhaps the most over-determined, over-signifying moment in a play redolent with its debts to the prior tradition of revenge and love tragedy on the Renaissance stage. As Quentin Tarantino assumes that postmodern viewers will recall the Hong Kong crime epics and 1970 s blaxploitation films he obsessively quotes, so Ford assumes his 
first audience will readily recall Shakespeare's Othello (who kills his wife for love), Romeo (who dies besides his wife for love) and Hamlet, whose eloquence is never more ahundant than when speaking of death and love. Giovanni is all these. He is Titus, arriving at a Thyestean feast, determined to kill and so feast upon his enemies. He is also Hieronimo, Kyd's great anguished, revenging hero in The Spanish Tragedy, a play that no one who saw it in early modern London, it seems, ever forgot. Hieronimo stabs his enemy, and then excises his own tongue. Giovamni does not go that far, hut then in conventional moral terms having slept with, impregnated, killed and anatomized his sister, he hardly needs further outrage to sensationalize his story for the audience. His verbal and visual excess can be seen to fulfil the potential unleashed by all these prior tragic scenarios, which Giovanni himself appears to have included in all the reading for which Friar Bonaventura chastises him at the heginning of the play: 'Dispute no more in this, for know, young man, | These are no school points. Nice philosophy | May tolerate unlikely arguments, | But Heaven admits no jest [...]' (I.i.1-4). Giovanni's excess is such, however, that fulfilling that potential seems to result in those scenarios referencing multiple source plays from the early modern theatre collapsing on top of cach other amidst the fremzy of blood and signification which Giovanni himself unleashes. Things are by no means what they so luridly appear to he. The more Giovanni calls them into being through language, the more 'words' and 'things' are severed one from the other. The obvious point to begin thinking about this process is the tip of Giovanni's dagger. Here, he tells us, is now perched Annabella's heart.

He needs to explain this heart for a range of reasons. Firstly, he is proud of his Caligula-like skill at carving up his sister. Weirdly enough, he seeks the approval of his enemies. Secondly, if presented with one in its disembodied state, which of us (cardiac specialists aside) could tell one human heart from another? Thirdly, whatever we are led to gaze upon, either 'live' on stage, or in the stage imaginary of reading the play, cannot surely be what Giovanni insists it is, unless that is, as Catherine Silverstone remarks in her chapter in this volume, we are to imagine a truly repugnant snuff theatre.

If not the 'real' thing, what would serve as its simulation? Either a mammalian but not human heart, fresh and dripping blood, I suggest, or a complete simulation, a harmlessly lurid synthetic prop. The more you think about either kind of prop the less 'real' either will seem, and the more cognitive dissonance will appear between 
Giovanni's words and deeds. He promises to the Friar to make himself and Annabella 'One soul, one flesh, one love, one heart, one all?' (I.i.34). Michael Neill has brilliantly expounded the potential resonance between the play's cardiac obsession, early modern anatomy and Catholic doctrines of the sacred heart. ${ }^{3}$ From Neill's perspective, Ford fulfils the potential of anatomy theatre, bringing emblems of the heart to vivid stage life. From the perspective of deconstruction, however, it can be seen that Ford only appears to do so. Rather it can be seen that, in a further move, Ford turns those terms inside out, rendering them incompatible. The very brilliance of Ford's staging and rhetoric undoes itsclf. One heart is played by no heart at all. The score becomes 'nil all'. This then is the truly 'strange riddle' (V.vi.29) inquired into by Vasques (Soranzo's serving man); and is then the real basis for the mocking, tendentious hollowness of the Cardinal's lines, now so famous as the title of the play itself. The first published text of the play uses the emerging capacity of print culture to gesture towards this, literally unspeakable, hollowness. I will come back to these lines, as well as to the play's very thorough preparing of the grounds of its own undoing. But first I will deal with the issue of what we might mean by 'deconstruction'.

To 'deconstruct' a text, $O E D$ tells us, is 'to analyse and reinterpret in accordance with the "strategy" associated with Jacques Derrida', ${ }^{4}$ in other words to follow through the implications of the epochal readings of philosophical and ethnographic texts Derrida initiated in Writing and Difference and Of Grammatology in the 1960s.5 Deconstruction, since the 1960s, has become a fashionable all-purpose signifier. As the first $O E D$ citation for 'deconstructionism' remarks as long ago as 1980, 'the coincidence of vulgar with erudite deconstructionism is a circumstance worth remarking'. I will call these two forms 'weak' and 'strong' deconstruction. These coexist in current discourse in a way that is emblematic of Derrida's underlying method. For 'weak' deconstruction is lazy, almost flippant, yet prevalent. Strong deconstruction, at its best, in contrast, is unrelenting and exhausting to conduct and to assimilate. Since it can be found in fewer books and articles, it is numerically much weaker than its inferior sibling. Weak deconstruction abounds. Customary users of the term in its weak sense usually intend to deconstruct a sign system or a cultural practice. Their meaning is well summed up by the Merriam-Webster Dictionary, the American equivalent of the $O E D$, which gives for deconstruct 'to adapt or separate the elements for use in an ironic or radically new way', offering a lovely example from American Vogue of someone 
who 'uses his masterly tailoring to deconstruct the classics'? In terms of the fashion industry, Vivienne Westwood is a famous example of someone who thus 'deconstructs' prior styles, adapting, for example, elements of eighteenth-century couture, "in an ironic or radically new way'. In terms of cultural or semiotic analysis, the essays on French culture Roland Barthes pionecred in his Mythologies, or the accounts of glohal media culture Umberts Eco offers in his Travels in Hyperreality work likewise towards a radical, detached, ironic critique of the operations of culture. Thev 'deconstruct', they disrupt, the bourgeois surface of modern western lifestyles. In this weaker sense, Ford in his play can be said to deconstruct the early modern dynastic family unit, and the hold of the Catholic Church on Renaissance Italy. When literary/aesthetic analysis likewise 'deconstructs', most often it aims to decode, analyse and critique.

In its stronger and more challenging form, however, analysing 'in accordance with the "strategy" associated with Jacques Derrida' requires a good deal more from its practitioners, those attempting, as here, to read in his name. Derrida was a trained philosopher. In his most celebrated and influential 1960s works he approaches key texts in the western philosophical tradition from a linguistic perspective showing how, by paying ruthlessly literal attention to all a text says, and reading its metaphorical figures as intrinsic to its ethical thought, it cannot really mean what it has often been held to mean. This reading procedure is derived from the work of Ferdinand de Saussure's Course in General Linguistics, perhaps the most influential linguistics textbook ever written. The linguistic sign, Saussure famously tells us, is divided into two parts: the signifier, or sound concept, and the 'thing', or idea signified. We grasp the signified by decoding the signifier. Signifiers, in turn, can he grasped by their difference from each other. The relationship between the signifier and its signified is arbitrary: there is no fundamental, absolute relationship between signifier and signified. Rather, common understanding within language groups allows meaning to take place or, in Derrida's terms, appear to have done so. A single signifier, such as 'cat', in English, has a comparable signifier in French ('chat'), Italian ('gatto') and so on. The relationship hetween these signifiers is an arbitrary system of differences.

Now one cannot do much with a single arbitrary noun, or even several of them, beyond writing a reader for new entrants in primary schools, as in the famous Dr Seuss book The Cat in the Hat. For more complex signification, such as, for example, constructing or enacting a riveting Renaissance revenge/love play, you would 
obviously need more complex and extensive collections of signifiers. These too operate through readers or audience members locating meaning or 'signification' by understanding the difference between the terms made available to them.

In the 'real' world, where, for example, one must call and feed cats reliably lest they suffer, the system of linguistic difference Saussure specifies is arbitrary yet fixed. That is, we allow it to appear to be fixed in order to allow common-sense communication to take place. Derrida begs to differ. In his rereading of Saussure he shows that the relationship between signifier and signified is perpetually unreliable, perpetually opening a gap, aporia or abyss between the two halves of the sign. The inevitable difference between the two halves of Saussurean signs means that meaning is perpetually deferred or differed. Hence Derrida's famous coinage

'difference' (différence in French, combining the meanings of difference and deferral) to charactcrize those aspects of understanding, [which he] proposed [...] lay at the heart of language and thought, at work in all meaningful activities in an elusive and provisional way. ${ }^{8}$

One of the things that makes 'Tis Pity especially available or open to a deconstructive reading is the way it attempts to literalize or embody what lies at the 'heart of language and thought', what, in another context, Graham Greene named The Heart of the Matter, or what in The Wasteland T. S. Eliot evokes as being 'the heart of light the silence'. ${ }^{9}$

At this 'heart' Derrida perceives not ultimate, fixed meaning but only 'elusive and provisional' différence, a realm something like that depicted in the opening of the Book of Genesis before the creation of the world, when, in the words of the King James Bible, the 'earth was without form and void, and darkness was upon the face of the deep' (Gen. 1:2). These verses are a crucial zone of différence in Derrida's reading practice, for they enunciate within the zone 'without form and void' an interface between speech and text, between the written and the oral. Genesis 1 is one of the oldest written texts in the Judeo-Christian tradition we possess, passed down from scroll to parchment, into print and now cyberspace in a process continuous since the first manuscripts were produced around $900 \mathrm{BC}$. Yet this written text, which the 'peoples of the book' (adherents to Judaic and Christian cultures and faith) have preserved for so long, privileges speech over the written word, for it is speech which, in the voice of God, creates the world. The word is 
spoken, then, before it is committed to text. The spoken word is primary and essential; the written is the secondary, proliferating afterglow of speech, the speech which promises 'full presence'. Derrida traces this dynamic not through scripture directly, but rather through Plato's Pharmakon. Writing, he insists, is prior to speech; the written underpins the oral, and not the other way round, as so long had been supposed. Writing, unlike speech, will not guarantee full 'presence'; rather it is governed by forms of absence. 'The precondition of discourse [...] the disappearance of any originary presence, is at once the condition of possibility and the condition of impossibility of untruth'. And this paradox is the always shifting heart of writing, governed in turn by the 'graphics of supplementarity, which supplies, for the lack of a full unity, another unit that comes to relieve it, being enough the same and enough other so that it can replace by addition'.10

Writing and speech, 'absence' and 'presence', in Derrida's terms, are linked, dynamic binaries. As this approach invites us to disrupt the smoothly untroubled play of difference Saussure evokes, so, over the last 40 years, it has seemed, Derrida has invited us to disrupt 'truly', to deconstruct the orderly surface of classical writing. The 'disappearance of the good-father-capital-sun is thus the precondition of discourse'.11 Disrupting the power of the father-sun-god complex which has governed western assumptions about the priority and divinity of speech might lead then also to Roland Barthes's famous proclamation of the 'Death of the Author', whose demise would reveal that 'Writing is that neutral, composite, oblique space where our subject slips away, the negative where all identity is lost, starting with the very identity of the body writing'. 12 Barthes wrote these words within the same cultural moment as Derrida was 'deconstructing' Plato, when Barthes was transforming himself into a proto-deconstructionist, nearly 15 years before the OED caught sight of the term in print in an English text.

The core metaphors Derrida links together in the phrase quoted, the form of the good, the father, the capital (or head, from the Latin caput) and the sun come under sustained attack throughout 'Tis Pity. The play, in these terms, can be seen to inhabit something like the spirit of vehement play (often called Nietzschean) which both Barthes and Derrida bring to their playful yet earnest rereading and rewritings of literary and philosophical tradition, in which 'no moment, no mark (grapheme) is too small for examination $[\ldots$ and ...] conflicts between speaking and writing are insinuated [...] legalistic [...] casuistic'.13 Like Ford's Giovanni they aimed to deconstruct the world of texts so comprehensively that they would 
come to seem part of a world turned upside down. Thirty years before Derrida and Barthes, the French theatre practitioner and theorist Antonin Artaud in his 1938 essay 'Theatre and the Plague' had divined a comparable spirit in Ford's play when he claimed it as one that 'upsets our sensual tranquillity, releases our repressed subconscious, drives us to a kind of potential rebellion', opening the doors of perception out to a realm where "all true freedom is dark, infallibly identified with sexual freedom, also dark, without knowing exactly why'. ${ }^{4}$ Artaud of course proposes a fully potent, essentializing reading of the play. When he describes the play he has, as it were, become Giovanni. Giovanni is a 'deconstructor', one who deconstructs the social facades of Parma, his father's ambitions and his sister's body. Yet in terms of the binary proposed earlier, Giovanni is a 'weak' deconstructor; the play that contains him, I suggest, has a wider ambit, deconstructing in turn Giovanni's own powerful deconstructing energies. To see this, we can return where we began, with Annabella's heart.

This climactic cardiac moment is carefully overprepared for throughout the play, its texture constantly gesturing towards what we are about to see for which, the play anticipates, we will be duly ungrateful, no matter how we keep our eyes fixed on what the 'unspeakable' Giovanni takes such gleeful pains to enunciate. Before the play begins, Giovanni, in his confession to the Friar, has '[e/mptied the storehouse of [his] thoughts and heart' (I.i.14), equating here 'heart' with 'soul'. He seeks to replenish the heart thus 'emptied' through his union with Annabella, so that joined together they may be '[olne soul, one flesh, one love, one heart, one all' (I.i.34). Here again Giovanni sounds like someone who has read early modern love poetry very attentively. His anatomizing at the end of the play shows that he has conducted his reading in an obsessively literal way, linking tenor with vehicle, the literal and metaphorical. The seizure of Annabella's heart is something she rapturously consents to, as she surrenders to him her 'captive heart' (l.ii.266). This follows the gestic moment where Giovanni offers her the prior right to anatomize him:

GIOVANNI: Here! Offers bis dagger to her ANNABELLA: What to do?

GIOVANNI: And here's my breast; strike home!

Rip up my bosom; there thou shalt behold A heart in which is writ the truth I speak. 
The procedure he urges here is precisely that he practises later, and which his enemy (and double) 15 Soranzo threatens when he discovers Annabella is pregnant; to find the name of her lover, he cries, 'I'll rip up thy heart, | And find it there' (IV.iii.52-53).16

In the fiction of the play, Giovanni thus rips up Annabella's heart on behalf of all three of them, emptying her storehouse both of heart and the embryo it was supporting, the better to express the vengeful anguish of his own 'heart'. This proves to be too extreme a testing of the links berween poetic metaphors of the heart, the theology of the sacred heart of Jesus (which, as Michael Neill shows, Ford draws on) and the 'heart' 'itself'. The terms engaged in Giovanni's final gest, his tableau-like entrance into V.vi, collapse on top of each other. If the point of the anatomy was to bring things to light, then Giovanni's gesture results in obscurity. Giovanni's exit from the scene before hints towards this disassemblage: 'Shrink not, courageous hand; stand up, my heart, I And boldly act my last and greatest part!' (V.v.105-6). The terms Giovanni uses here fold back upon themselves. 'My heart' invokes the use of heart as a term of endearment and companionship available in the period, as when, much earlier in the play, Giovanni instructs Anabella to 'keep well my heart' (II.i.32). As his 'heart' companion or dear friend, she should keep well; as his heart, she should keep well, for where would he be without his heart? Her heart is his to use, which is the riddle couched within 'stand up my heart'; he will shortly bring this phallic command to his self-devised theatre of revenge, entering 'with a heart upon his dagger', holding it before him as his weapon. This non-heart unmakes his enterprise to achieve fullness of meaning and self-actualization in his own play's last scene. For the oneness Giovanni sought through the language and action of the heart is rather a return to blankness and nullity. Crashaw suggests as much with his epigraph for Ford: 'Thou cheats't us Ford, mak'st one seeme two by Art. I What is Loves Sacrifice, but the broken Heart?' 17 Crashaw riddles with the titles of two other Ford plays which revolve around sacrificial love and gruesomely-staged deaths, implying that Ford has outdone his own ingenuity, with all three plays articulating one and the same thing. The mammalian for otherwise contrived) heart Giovanni is then compelled to proffer as a metonymic substitute for a 'real' one serves to undo all this furious verbal and embodied playmaking, making bare also the emptiness of the play's (and Giovanni's) devices for readers and audiences alike. Giovanni is too flushed with his triumphs to be aware of this, but the play coolly frames his adolescent excess. Perhaps this is the 'real' reason why Tom Stoppard framed his hit 1982 comedy The Real 
Thing around a sub-plot where his heroine Annic travels to Glasgow to star as Annabella in a production of 'Tis Pity. This seems to play partly as a joke against the Scottish hinterlands. ${ }^{18}$ In Scotland, Ford might play as the 'real' thing, real quality theatre, 'real' emotion and love; in London, where most of the play is sct and where of course it was first staged, audiences would know better. In Derridean terms they would perceive there could be things proffered as props, but these could never be 'real'; and this thing called 'love', the pursuit of which both Ford and Stoppard make so central, would remain elusive also, no matter how poetically or viscerally their invented characters appear to strive for it. ${ }^{19}$

Threading so profusely through the play and the cast the rhetoric of the heart serves to underline that elusiveness. The play makes and then unmakes its central verbal premise. What remains is a scenario that is repugnant if you take Giovanni at his word for what he claims to have done to Annabella's corpse; or ridiculous if you attend to the gap between these claims and the enfeebled means by which any stage production must gesture towards them. The capacity of the text to make and unmake itself runs all the way to the play's last couplet, which I will discuss later. It makes the play seem like a splendid theatrical example of the kind of seventeenthcentury text Stanley Fish calls Self-Consuming Artifacts. In his terms, 'to read' (or watch) the play 'is to use it up', creating an interpretation 'in which the work disappears', 20 since working through the work creates a process whereby the work confounds its own premises. In this reading, Ford, not Giovanni, emerges as the stronger deconstructor. Neither Ford nor Giovanni may have read William Harvey's famous treatise published in 1628 as Exercitatio Anatomica de Motu Cordis et Sanguinis in Animalibus (Anatomical Exercises on the Motion of the Heart and Blood in Animals, it was published in England in 1653), but the coincidence is suggestive. For in demonstrating for the first time how blood really did circulate from the heart and through mammalian bodies, Harvey initiates an epoch of literal, empirical exploration and verbal description of the heart and its function within the body machine. This new scientific perspective then made redundant the previous metaphorical grasp of the 'motion of the heart'. 21 Giovanni tries to unite both perspectives. The play, published five years after Harvey's treatise, shows this to be unsustainable.

The reactions depicted from his father and sister (the only family the play gives him) suggest a stronger grasp on the way the undoable might register also as the unsayable, either eschewing words altogether or using them to work beyond them to what words, 
whether written or spoken, could not possibly fully say. Where Giovanni continues to be profuse in his eloquence to the last, Annabella expires with a dense, deconstructive pun: 'Brother unkind, unkind' (V.v.93). He is unkind, having been not gentle in his stabbing of her. Then too he has 'unkinned' her, in a literal sense, since killing her eliminates her as his sister. He has taken one of his two kin away. Giovanni thinks not so, of course, here literalizing the vows they made earlier: 'Love me, or kill me brother. $[$ [...] Love me, or kill me, sister' (I.i. 276, 279). Ford clearly assumed his first audiences would know both how incest narratives unfold in fiction and would recall the fates of Othello and Desdemona and Romeo and Juliet. Loving and killing fold one into the other. Giovanni is then an 'unkind' brother and the closest kin imaginable. Annabella then reacts to the unspeakable with a line that is unsayable and perhaps not playable; how could an actor utter so many contradictions at once? At this point the publication of the play for the eager reading 'audience' of Caroline London might be read as a gesture towards that unplayability, for contradictions which may not be staged may more easily be weighed by readers.

The cancellation of his father Florio is rhetorically simpler. He dies mid-line: 'Cursed man! - Have I lived to-' (V.vi.61). With the evidence of 'Annabella' now paraded before them, the onlookers are in no doubt as to what causes Florio's demise: 'see what thou hast done, | Broke thy old father's heart!' (V.vi.63). Florio's death is the inverse of the riddle of Annabella's heart. For Florio may indeed be heartbroken, and the pathological cause of death may indeed be cardiac arrest. The characters onstage can 'see' Florio is dying, hut they cannot see his breaking heart. They make the obvious metaphorical link; that it is Giovanni who has broken his father's heart, just as he gleefully informs them that his 'hands have from her bosom ripp'd this heart' (V.vi.59). The proclamation of this previous 'unkind' action leads to Florio's 'unkind death'. With his father's death Giovanni becomes fully 'unkinned', having no kin left in Parma. His own death cancels the family completely. Giovanni's assumption of patriarchal control, that it is his destiny to love, kill and revenge, undoes his patriarchal family from within, a selfdeconstructing triumph made the more complete because of the fact that their mother is mentioned ('even by our mother's dust I charge you' [I.ii. 277]) in such a way that makes clear she is dead long before the story begins. Florio dies mid-line to make clear his death is to be very sudden, and to underline the forms of unmeaning Giovanni's 'unkind' actions bring the family to. Not even the verse of the father can make sense, so radical is the attack of the son upon 
the family, conducted, mistakenly, to advance its glory. John Lanchester characterizes such a deconstructive moment as like the action of

a snake permanently and necessarily eating its own tail. This process is fluid and constant, but at moments the perpetual process of deferral stalls and collapses in on itself. Derrida called this moment an 'aporia,' from a Greek term meaning 'impasse'.22

In terms of Giovanni's impulses, this fluid process is in train as the play begins. The death of his entire family, including his brotherin-law, arrests that impasse, momentarily. Again though Ford takes a wider view; the conclusion to his play offers a wider aporia that encompasses the play as a whole, suggesting a structure just like that Lanchester figure evokes. Just as the snake swallows its own tail, so the end of the play envelops the rest. It happens this way.

As is customary in a Renaissance play, order is restored at its end. The audience is invited to view the ruins of Soranzo's feast, with Giovanni, Florio and Soranzo lying dead on the stage. Beyond these deaths a sense of calm needs to prevail. The Cardinal takes charge, dispensing justice and, in being given the last lines of the play to speak, summarizing what the audience has witnessed. He orders that Putana, Annabella's servant, be burnt to death for her complicity in the crimes committed, and banishes Vasques on pain of death. He then confiscates 'all the gold and jewels, or whatsoever' from the family estate 'to the Pope's proper use' (V.vi.157-59). With a quatrain of two heroic couplets (rhymed iambic pentameter), the Cardinal then closes the play:

We shall have time

To talk at large of all; but never yet

Incest and murder so strangely met.

Of one so young, so rich in Nature's store,

Who could not say, 'Tis pity she's a whore.

$$
\text { (V.vi.164-68) }
$$

Here the Cardinal's blandly rhymed assurance projects a confidence that the audience will agree with his judgement of the case, but his credibility is questionable. Catholic friars and priests (as with Friar Laurence in Romeo and Juliet and Bonaventura in Ford's play) are frequently sympathetic figures in early modern playtexts. Catholic cardinals, however, are treated more harshly, projected as sympto- 
matic of both the Roman Catholic Church and the morass of iniquity and sexual impropriety which is integral to the way the English in the seventeenth century imagined Italy to be. Excellent examples of such cardinals include those in Webster's two great tragedies, The White Deuil and The Duchess of Malfi, which Ford clearly knew well, and The Cardinal in Shirley's 1640 tragedy of that name. The justice the Cardinal dispenses demonstrates harshness towards unwitting victims, as in his demand that Putana be burnt: she must be punished by transference for Annabella's crimes, as Giovanni has taken his sister beyond the realm where the Cardinal can pass judgement. Moreover, his confiscations of the family's estate suggest the greed for which the Catholic Church was notorious, and which was a point of contention throughout Europe from the beginnings of the Reformation in the early sixteenth century.

The Cardinal's last phrase, 'tis pity she's a whore, envelops the play, since this last half line is also the title of it, and this would seem to suggest that if the Cardinal endorses the play's title then, in return, the play endorses the Cardinal's perspective, one being complicit with the other. Yet this catchphrase (so memorable as a title for a play) makes a contradictory kind of sense. The Cardinal insists that Annabella was a 'whore'. Technically this judgement would be correct, since she committed adultery and incest. But reading this judgement over against the presentation of Annabella suggests its limitations. Ford establishes Annabella as a sympathetic figure, dominated by helpless pathos and, in her last moments, the unwitting victim of her brother's grandiose desires. The model here is Shakespeare's Desdemona, whose tragic death became an often repeated archetype on the London stage. The Cardinal assumes the audience will agree with him, but it is questionable how complete that assent is, though of course they are liable to remember his memorable catchphrase. Ford himself seems to have registered this as problem, in his dedication protesting that the 'gravity of the subject may easily excuse the lightness of the title' (19-20).

The Cardinal treats his phrase as irrefutable: 'who could not say [...]'. The question rather seems to be, if they did say it, what could they possibly mean? If you took the harsh moral line of the Cardinal, you would consider her a whore. But if you did so think of her, how could you pity her? You would rather eagerly condemn her to her fate, with as much relish as the Cardinal sentences Putana. If Annabella is a whore, then it is not a pity. If on the other hand you pity her, recalling in particular her untimely, underplayed death, then you would not think of her as a whore. In this sense, Ford takes 
advantage of the rhyming couplet which breaks each line so readily into two, with a clear caesura or cut between 'who could not say' and 'tis pity'. The second half of the line breaks equally into two components, each in turn governed by the verbal clause which precedes them: 'tis pity / she's a whore'. Who could not say 'tis pity. Who could not say she's a whore.

At first the line is seamless, and then it reads against itself. She is a whore and not a whore. She is an object of pity and yet not an object of pity. The phrase of course draws us back into the play as a whole, returning us to its beginning. Here in a few surviving copies of the first published quarto of the play, we find a commendatory verse by Thomas Ellice, which seems to grasp the paradox of the Cardinal's claim, and its relationship to the play which that claim appears to govern:

With admiration I beheld this Whore

Adorn'd with beauty $[. .$.

Thy name herein shall endure

To th'end of age; and Annabella be

Gloriously fair, even in her infamy.

$$
(1-2,8-10)
$$

The play (and Annabella) both are and are not whores. They both are and are not admirable. The play, Ellice's early reading suggests, refuses to take the Cardinal's side, finding both play and heroine 'gloriously fair'; yet he refuses to take away the title. It undoes then what it most eagerly seeks to assert. In some of his writings, Derrida subjects words to what he calls 'erasure', striking a line through a word he cannot dispense with, reminding readers that the word does/not represent what it appears to.

The 1633 text of the play represents this undecidability in visual form, using italics and capital letters for the phrase 'Tis pitty shee's a Whoore, ${ }^{23}$ It is quite common for early modern printed texts to use capitals in the middle of lines where modern usage would not. It is common too for a word or phrase to be placed in italic for emphasis over against the roman typeface which, by 1633, had become standard. Ford provided dedications and other ancillary matter for his plays, so we know he had some involvement in seeing the text into print. Modern editors of his plays concur that the way the first printed texts use italics and capitals for emphasis suggests authorial involvement. 'Such use of italic emphasis has a distinctively authorial stamp', A. T'. Moore suggests, 'and is an outstanding feature of several early texts of Ford's works. It is the mark of a 
dramatist who gave some thought to the literary form of his plays'.24 Derek Roper concurs, pointing out that of all the playtexts Nicholas Okes printed between 1628 and 1635, it is only his edition of ' $T$ is Pity that uses italic type in a striking way. ${ }^{25}$ It is very likely that Ford oversaw the setting of the play into type, and that the play's final words appeared thus in print at Ford's request; and were thus made available to the wider audience of readers beyond the Phoenix in Drury Lane where the play was first performed, for the publication of Ford's text is part of the newly-expanding market for printed playtexts in the $1630 \mathrm{~s} .26$

On a first reading, you can grasp the visual presentation of the phrase as a self-referential joke, arcing back through the play you just rcad. Wilde's famous 1895 farce repeats this device, proclaiming its theme and its title in its last line as 'the importance of being earnest'. Wilde's text too is wilfully deconstructive. In Ford's case the phrase reads as self-refuting. This is partly because of the internal contradictions within the Cardinal's claims. Partly too this has to do with the gap or aporia between the written and the oral, which Derrida has explored so searchingly. For a playtext is an amphibious printed object. Words on the page are presented as they might have been said on stage, or as they might be in future performance. The script can give you the look of the words, but not their sound. The gap between 'look' and 'sound' is unbridgeable. In these tcrms the italics granted to the Cardinal's phrase are unsayable. Readers will take them to be both his clever dismissal of Annabella and the title of the play. You could say (or read) these lines suavely, urbanely, even sadly, but you could not say them both as the title and the dismissal. That is, audience members could not distinguish the sound of one from the other. Either the title of the play crases the Cardinal's remarks, or the Cardinal's remarks cancel the title of the play. Readers of the 'written' text are privileged over those who merely hear it, since in reading you can entertain the possibility of both readings at once. They occupy the same half line of space on the printed page, but suggest radically different readings of the text encountered. The effect is then to cancel the savage illumination Giovanni strives to bring to bear in the last scene of the play, and follow the path back from the last line to the title page and the first lines, to attempt yet once more the impossible yet rewarding task of resolving the undecidable, a task never completed because its terms come to us in the constant flux of deferral. 
150 'TIS PITY SHE'S A WHORE

\section{Acknowledgements}

Thanks to Michael Neill, for his exemplarity, to Sophie Tomlinson, to Sonia Massai and Catherine Silverstone, who first invited me to rethink Ford, to the members of the 'Tis Pity seminar at the 2006 SAA meeting in Philadelphia; and to the Faculty of Arts and Social Sciences at the University of Waikato, who funded the conference travel to that SAA.

\section{Notes}

1 Selected Plays of Joln Ford, cd. Colin Gibson (Cambridge: Cambridgo University Press, 1986); 'Tis Pity, s.d. following line 9; V.vi.24-30. All references to the play are from this edition.

2 Text from Poetical Works, ed. Sir Herbert Gricrson (Oxford: Oxford University Press, 1968 (1933), p. 35.

3 Sec his " "What Strange Riddle's This?": Deciphering 'Tis Pity She's a W'bore', in Joln Ford: Critical Revisions, ed. Michael Neill (Cambridge: Cambridge University Press, 1988), pp. 153-81. This volume is an excellent example of contextualized formalist and historicist readings of Ford which the essays here by myself and Catherine Silverstone seck to disrupt. For an excellent recent approach to reading the 'heart' in this period through literary, cultural and historical lenses, see William Slights's The Heart in the Age of Shakespeare (Cambridge: Cambridge University Press, 2008).

4 OED online 'deconstruct' s.v. 1.a.

5 For an excellent introduction to Derrida's work, sce the entry 'Jacques Derrida' in the Stanford Encyclopedia of Philosophy, onlinc: hetp://plato.stanford.edu/ entries/derrida/.

6 OED online, 'deconstructionism' s.v. 1.b, ciring R. M. Adams.

7 Merriam-Webster anline, 'deconstruct'.

8 Derek Attridge and Thomas Baldwin, 'Obituary: Jacques Derrida', Guardian Weekly (15-21 October 2004), p. 30 .

9 T. S. Elior, The Complete Poems and Plays 1909-1950 (San Diego, CA: Harcoutt, Brace, Jovanovich, 1971), l. 41, p. 38.

10 Jaçues Derrida, 'Play: from the Pharmakon to the Letter and from Blindness to the Supplement', in The Norton Atthology of Theory and Criticism, ed. Vincent B. Leitch (Ncw York: Norton, 2001), p. 1875. All direct citations from theorists are from this volume. Students are highly recommended to consult the readings in this volume, along with the consummately helpftel introductions and suggestions for further reading.

11 Derrida, Norton Antbology of Theory and Criticism, p. 1875.

12 Batthes, Norton Anthology of Theory and Criticism, p. 1466.

13 Andrew DuBois, 'Introduction', Close Reading: the Reader, cd. Frank Lentricchia and Andrew Dubois (Durham, NC: Duke University Press, 2003), p. 35.

14 Antonin Artaud, The Theatre and lts Double, trans. Victor Corti (London: John Calder, 1985), pp. 19, 25.

15 They are both 'husband' and 'lover' to Annabella.

16 See Michael Neill's cssay, pp. 156-57, for anecdotes of anatomized hearts from the period which it is daimed could he read in just such ways.

17 Richard Crashaw, 'Vpon Ford's two Tragedyes Loves Sacrifice and The Broken Heart', in his Steps to the Temple 1646, together with Selected Poems in Manuscript (Menston: Scolar Press, 1970), p. 45. 
THE DECONSTRUCTING 'TIS PITY? 151

18 This might also draw on the reputation of Glasgow's Citizens' Theatte for its 'strongly visual and visceral form of theatre, particularly suited to the production of the classic plays of the European repertoirc', 'University of Glasgow Special Collections: Citizens' Thearre', online: http://special.lit.gla.ac.uk/STA/citzcat/index.html.

19 For more on Stoppard's appropriation of Ford, see my 'Postmodern Tragedy: Returning to John Ford', in Tragedy in Transition, ed. Sarah Annes Brown and Catherine Silverstonc (Oxford: Blackwell, 2007), pp. 248-49.

20 Stanley Fish, Self-Consuming Artifacts: the Experience of Senententh-Century Literature (Berkeley, CA: University of California Press, 1972), p. 3. Fish's earlier Surprised by Sin: the Reader in Paradise Lost is another excmplary application of deconstructive thetoric strategies to a canonical carly modern text.

21 For a concise assessment of Harvey's experiments and their significance, see Andrew Gregory, Harvey's Heart: The Discovery of Blood Circulation (Cambridge: Icon Books, 2001),

22 John Lanchester, 'Melting into Air', The New' Yorker (10 Novemher, 2008), pp. 80-84, p. 84 .

23 This line is from the Scolar Press facsimile of the play John Ford: 'Tis Pity She's a Whore 1633 (Mcnston: Scolar Press, 1969).

24 A. T. Moore, in his edition of Love's Sacrifice (Manchester: Manchester University Press, 2002), p. 273.

25 Sec Derek Roper's edition of Tis Pity She's a Whore (London: Methuen, 1975), p. lxiii. For a summary of evidence for Ford attending so carefully to the visuality of his printed playtexts, se R. J. Fehrenbach's 'Typographical Variation in Ford's Texts: Accidentals or Substantives', in 'Concord in Discord': the Play's of John Ford, 1586-1986, ed. Donald K. Anderson, Jr (New York: AMS Press, 1986), pp. 265-94.

26 For more on this audience and its reading practices, see Martin Butler's "The Caroline Audience', in his Theatre and Crisis 1632-1640 (Cambridge: Cambridge University Press, 1984), pp. 101-40. 